\title{
TATA KELOLA ANGGARAN DESA YANG BERSUMBER APBN DALAM RANGKA MEWUJUDKAN PEMBANGUNAN MASYARAKAT PINGGIRAN BERBASIS PEMERATAAN PEMBANGUNAN PEDESAAN DALAM PERSPEKTIF NAWA CITA (STUDI KASUS DI WILAYAH CIAYUMAJAKUNING)
}

\author{
Sugianto $^{1}$, Leliya $^{2}$, Ubaidillah $^{3}$ \\ ${ }^{1}$ sugiantoaphi@gmail.com \\ ${ }^{2}$ leliya@syekhnurjati.ac.id \\ 3 ubaidillah_firly@yahoo.com
}

\begin{abstract}
Rural development in an integral part of regional development and national development as an effort to improve the quality of community's life. The implementation of this rural development program is very important in the context of national development because rural areas occupy the largest portion in the entire country. The purpose of this study was to find out the village budget management sourced from the state budget in order to realize rural community development based on rural development in the perspective of Nawa Cita and the role of the village government in running the Nawa Cita program on peripheral community development on village government budget management based on people's interest in order to realize equitable development.
\end{abstract}

This study used a qualitative approach in order to investigate and understand the phenomena such as what happens, why it happens, and how it happens while understanding a social situation, events, and interaction roles. Data collection was carried out by conducting interview with the Head of BPMPD Department of Cirebon Regency, the Head of BPMPD Department of Kuningan Regency, the Head of BPMPD Department of Majalengka Regency and the Head of BPMPD Department of Indramayu Regency and all village heads in Cirebon, Indramayu, Majalengka, and Kuningan Regions. As well as the data were obtained from the documents in regency, disctrict, and village.

The result of this study showed that village as the frontline of the development has strategic role in the success of the Nawa Cita Program. The village budget management is based on the principle of transparency, accountability, participatory, efficient, effective, orderly and budgetary discipline by paying attention to the justice principles, propriety and benefits for the village community. The implementation of activities in the APBD is carried out by the implementing team consisting of the elements from village apparatus and community institutions and supervised by the BPD, at the end of each fiscal year the Village Head has the obligation to submit a village government management report (LPPD) to the regional head through sub-district head and submit information to the $L P P D$ to the BPD. 
Keywords: Government, Village, Nawa Cita, Budget, Development.

\section{PENDAHULUAN}

Pada Pemilihan umum Presiden 2014 salah satu calon menjadikan Program Nawacita merupakan istilah visi-misi dari pasangan calon presiden/calon wakil presiden Joko Widodo/Jusuf Kalla. Dalam visi/misi tersebut dipaparkan sembilan agenda pokok pemerintahannya. Setelah menjadi Presiden terpilih, Jokowidodo- Jusuf Kalla langsung menerapkan program Nawa Cita ke dalam program-program pemerintahannya, yaitu melalui sebuah kabinet yang disebut dengan kabinet kerja. Komposisi dan struktur Kabinet Kerja tersebut dirancang untuk mengakomodir agenda-agenda yang termuat dalam Nawa Cita. Nawacita ini adalah merupakan sembilan program yang diharus diwujudkan oleh Jokowidodo -Jusuf Kalla agar supaya Indonesia lebih mandiri, yaitu mandiri dalam bidang ideologi, politik, ekonomi, sosial dan budaya. Menjadi bangsa yang tak bisa didikte oleh negara lain. ${ }^{1}$

Nawacita merupakan sebagai Prgram Unggulan yang salah satunya pada Poin 3 dimana salah satunya adalah membangun Indonesia dari pinggiran dengan memperkuat daerah-daerah dan desa dalam kerangka Negara kesatuan. Jalan perubahan "membangun Indonesia dari pinggiran dengan memperkuat daerah-daerah dan desa dalam kerangka Negara kesatuan" menjadi sangat penting untuk dianalisa mengingat relevansinya dengan kebutuhan mendasar masyarakat desa serta menjadi komoditas kampanye yang sangat seksi yang diblow up oleh masing-masing pasangan capres-cawapres melalui janji pengucuran dana desa sebesar Rp. 1 milyar pertahun meskipun sesungguhnya hal tersebut menjadi amanat Undang-undang Desa Nomor 6 tahun 2014 yang belakangan diklaim oleh banyak politisi sebagai produk yang didukung penuh partainya. ${ }^{2}$

Tujuan pembangunan nasional secara umum adalah untuk membangun bangsa yang maju, mandiri, dan sejahtera. Hal ini sesuai dengan tujuan yang tercantum dalam alenia keempat Pembukaan UUD 1945 disebutkan bahwa hakikat pembangunan nasional adalah mencerdaskan kehidupan bangsa , menciptakan kesejahteraan umum, melindungi seluruh tumpah darah Indonesia, dan membantu melaksanakan ketertiban dunia dan perdamaian abadi. Berbicara mengenai tujuan pembangunan yang ketiga, bahwa

\footnotetext{
${ }^{1}$ www.indonesiacayo.com. Diunduh pada tanggal 5 Oktober 2017 Pukul 19.30

${ }^{2}$ www.kompasiana.com. Diunduh pada tanggal 5 Oktober 2017 Pukul 19.35
} 
masyarakat yang sejahtera pada taraf awal pembangunan adalah suatu masyarakat yang kebutuhan pokoknya terpenuhi. ${ }^{3}$

Pembangunan pedesaan adalah bagian integral dari pembangunan daerah dan pembangunan nasional sebagai upaya untuk meningkatkan kualitas hidup masyarakat. Idealnya, program-program pembangunan pedesaan bisa dilakukan secara berkelanjutan berdasarkan potensi dan kemampuan di wilayah setempat. Pelaksanaan program pembangunan pedesaan ini sangat penting dalam konteks pembangunan nasional karena wilayah pedesaan menempati porsi terbesar di seluruh negara. Oleh karena itu, pembangunan pedesaan perlu ditingkatkan, terutama sejak era reformasi yang ditandai dengan penerapan kebijakan desentralisasi dan otonomi daerah, melalui pelaksanaan program dan kegiatan yang berbasis masyarakat sehingga masyarakat daerah-daerah pinggiran menjadi semakin mandiri dalam membangun lingkungan daerahnya masingmasing.

Pemerintahan dalam pengertian yang sempit ialah segala aktivitas, tugas, fungsi, dan kewajiban yang dijalankan oleh lembaga yang berwenang mengelola dan mengatur jalannya sistem pemerintahan negara untuk mencapai tujuan negara. Hirarki pemerintahan di Indonesia mulai dari pemerintah pusat, provinsi, kabupaten/kota sampai desa. Dalam perjalanan ketatanegaraan Indonesia, sistem pemerintahan desa mulai coba diseragamkan lewat UU No. 5 Tahun 1979 tentang Desa, dan kemudian diatur dalam UU No. 32 Tahun 2004 Tentang Pemerintah daerah.

Desa dengan segenap atribut pemerintahannya adalah arena yang berhadapan langsung dengan rakyat. Pemerintahan desa adalah sentra kekuasaan politik lokal yang dipersonifikasi lewat Kepala Desa dan perangkatnya. Posisi pemerintahan desa juga sangat penting, mengingat mayoritas penduduk Indonesia tinggal di pedesaan.

Terkait dengan hal tersebut maka peneliti melakukan penelitian pada 4 kabupaten yaitu: Kabupaten Cirebon, Kabupaten Kuningan, Kabupaten Majalengka, dan Kabupaten Indramayu. Yang masing-masing memiliki jumlah:

1. Data desa di Kabupaten Cirebon memiliki total 420 desa

2. Data desa di Kabupaten Kuningan memiliki total 320 desa

3. Data desa di Kabupaten Majalengka memiliki total 330 desa

4. Data desa di Kabupaten Indramayu meiliki total 330 desa

\footnotetext{
${ }^{3}$ Repository.upi.edu diunduh pada tanggal 5 Oktober 2017 Pukul 19.43
} 
Pada prakteknya sistem pemerintahan Desa di Indonesia tidak seragam. Adanya gampong di Aceh, nagari di Sumatera Barat, marga di Palembang, dan banjar di Bali memperlihatkan warna lain pemerintahan desa. Upaya penyeragaman itu akhirnya membuat desa tidak mandiri. Kini, lewat UU Desa, pemerintah dan DPR berupaya mengembalikan kemandirian Desa dan pengakuan terhadap Desa berdasarkan asal usul. Di dalam UU Desa (UU No. 6 Tahun 2014), materi tentang pemerintahan desa terutama diatur pada pasal 23-66. ${ }^{4}$

Desa, sebuah kawasan yang sering dipersepsikan orang kota sebagai tempat yang nyaman dan indah. Meski kadang menyimpan sebuah potret buram kemiskinan. Citra buruk itulah yang hendak dihapus oleh pemerintah. Maka mulai tahun 2015 ini pemerintah secara bertahap menjalankan amanat yang tertera pada undang-undang tentang desa. Di dalamnya ada kewajiban pemerintah memberikan Dana Desa. "Dana Desa yang akan dikucurkan yaitu sebesar Rp 20 triliun”. Pembangunan Perdesaan Sesuai amanat UU No. 6 Tahun 2014, memang ditujukan untuk meningkatkan kesejahteraan dan kualitas hidup masyarakat desa. Caranya adalah dengan mendorong pembangunan desadesa mandiri dan berkelanjutan yang memiliki ketahanan sosial, ekonomi, dan lingkungan. Upaya mengurangi kesenjangan antara desa dan kota dilakukan dengan mempercepat pembangunan desa-desa mandiri serta membangun keterkaitan ekonomi lokal antara desa dan kota melalui pembangunan kawasan perdesaan ${ }^{5}$.

Pembangunan masyarakat saat ini sangat perlu di perhatikan,terlebih pembangunan di pedesaan. Desa adalah bagian dari perekonomian yang menyuplai kebutuhan masyarakat kota, misalnya hasil pertanian semacam beras atau sayur-sayuran. Namun, desa sebetulnya bisa menjadi basis pengembangan kewirausahaan jika dikelola dengan baik. Jadi, sebuah desa bisa saja tidak hanya identik dengan hasil pertanian, namun bisa mengembangkan usaha secara baik. Oleh karena itu, pembangunan perlu diimbangi dengan pemanfaatan Sumber Daya Manusia (SDM) dan Sumber Daya Alam (selanjutnya ditulis SDA) suatu desa tanpa melihat status pendidikan atau ekonomi masyarakat tersebut, sehingga pengangguran dan kemiskinan dapat berkurang.

Berdasarkan uraian tersebut diatas makapeneliti tertarik untuk melakukan penelitian dengan judul penelitian tentang Tata Kelola Anggaran Desa Yang 


\section{Bersumber APBN Dalam Rangka Mewujudkan Pembangunan Masyarakat Pinggiran Berbasis Pemerataan Pembangunan Pedesaan Dalam Perspektif Nawa Cita (Studi Kasus Di Wilayah Ciayumajakuning).}

\section{METODE PENELITIAN}

Penelitian ini menggunakan pendekatan kualitatif, menginvestigasi dan memahami fenomena seperti apa yang terjadi mengapa terjadi dan bagaimana terjadinya, sekaligus memahami suatu situasi social, peristiwa, peran interaksi. Hal ini dikarenakan pada penelitian ini peneliti menggunakan berbagai sumber data, teori, metode, dan investigator agar informasi yang disajikan konsisten. Pengumpulan data dalam penelitian kualitatif kualitas riset sangat tergantung pada kualitas dan kelengkapan data yang dihasilkan. Pertanyan yang selalu diperhatikan dalam pengumpulan data adalah apa, siapa, dimana, kapan, dan bagaimana. dalam penelitian ini digunakan teknik pengumpulan data yaitu wawancara, observasi dan analisis dokumen. Dalam penelitian ini wawancara memegang peran yang sangat penting karena metode wawancara digunakan peneliti untuk mengumpulkan data dan memperoleh informasi. Analisis data, untuk dilakukan analisis peneliti perlu menangkap, mencatat menginterprestasikan dan menyajikan informasi. Pada penelitian ini tahap-tahap analisis data dilakukan dengan metode trianguilasi data.

Pengumpulan data dengan melaksanakan tanya jawab langsung dengan responden yaitu Kepala Dinas BPMPD Kabupaten Cirebon, Kepala Dinas BPMPD Kabupaten Kuningan, Kepala Dinas BPMPD Kabupaten Majalengka, Kepala Dinas BPMPD Kabupaten Indramayu, dan seluruh Kepala Desa Se-Wialayah Cirebon, Indramayu, Majalengka, dan Kuningan. Serta data-data yang diperoleh dari dokumen-dokumen yang ada di Kabupaten, Kecamatan, Desa.

\section{HASIL DAN PEMBAHASAN}

Menurut Permendagri No. 56 Tahun 2015 tentang Kode dan Data Wilayah Administrasi Pemerintahan, Kabupaten Cirebon merupakan salah satu dari 27 kabupaten/kota atau 18 kabupaten dan 9 kota di Provinsi Jawa Barat”. Peraturan tersebut telah ditetapkan oleh Menteri Dalam Negeri pada tanggal 29 Juni 2015 di Jakarta untuk menggantikan peraturan sebelumnya yang sudah dicabut dan dinyatakan tidak berlaku 
yaitu Permendagri No. 39 Tahun 2015 tentang Kode dan Data Wilayah Administrasi Pemerintahan. Dari peraturan terbaru ini, maka dapat diketahui bahwa di Kabupaten Cirebon terdapat sebanyak 412 desa dan 12 kelurahan yang tersebar di 40 kecamatan. Dalam uraian di bawah ini diketahui bahwa Kecamatan Plumbon dengan jumlah desa sebanyak 15 desa merupakan "Kecamatan dengan Jumlah Desa Terbanyak di Kabupaten Cirebon Provinsi Jawa Barat”. Sedangkan Kecamatan Sumber dengan jumlah desa sebanyak 2 desa serta 12 kelurahan merupakan "Kecamatan dengan Jumlah Desa Paling Sedikit di Kabupaten Cirebon Provinsi Jawa Barat”.

Tabel 3.2 Jumlah Penduduk Kabupaten Cirebon pada Tahun 2015

\begin{tabular}{|l|l|c|c|c|}
\hline \multirow{2}{*}{ No } & \multirow{2}{*}{ Kecamatan } & \multicolumn{3}{|c|}{ Jumlah Penduduk } \\
\cline { 3 - 5 } & & Laki-laki & Perempuan & Jumlah Penduduk \\
\hline 1 & Waled & 25,544 & 26,392 & 51,936 \\
\hline 2 & Pasaleman & 14,055 & 16,591 & 30,646 \\
\hline 3 & Ciledug & 22,484 & 21,822 & 44,306 \\
\hline 4 & Pabuaran & 17,607 & 17,361 & 34,968 \\
\hline 5 & Losari & 30,186 & 28,901 & 59,087 \\
\hline 6 & Pabedilan & 30,033 & 29,561 & 59,594 \\
\hline 7 & Babakan & 35,577 & 34,967 & 70,544 \\
\hline 8 & Gebang & 32,074 & 31,347 & 63,421 \\
\hline 9 & Karangsembung & 18,644 & 18,020 & 36,664 \\
\hline 10 & Karangwareng & 15,380 & 14,656 & 30,036 \\
\hline 11 & Lemahabang & 27,399 & 26,196 & 53,595 \\
\hline 12 & Susukan Lebak & 20,887 & 19,734 & 40,621 \\
\hline 13 & Sedong & 22,470 & 20,984 & 43,454 \\
\hline 14 & Astanajapura & 40,162 & 30,099 & 70,261 \\
\hline 15 & Pangenan & 22,975 & 21,866 & 44,841 \\
\hline 16 & Mundu & 36,520 & 33,998 & 70,518 \\
\hline 17 & Beber & 21,216 & 19,255 & 40,471 \\
\hline 18 & Greged & 29,892 & 27,727 & 57,619 \\
\hline 19 & Talun & 34,894 & 32,691 & 67,585 \\
\hline 20 & Sumber & 43,991 & 41,939 & 85,930 \\
\hline 21 & Dukupuntang & 31,090 & 29,435 & 60,525 \\
\hline 22 & Palimanan & 31,749 & 28,902 & 60,651 \\
\hline 23 & Plumbon & 34,150 & 33,519 & 67,669 \\
\hline 24 & Depok & 31,591 & 30,535 & 62,126 \\
\hline 25 & Weru & 28,378 & 26,313 & 54,691 \\
\hline 26 & Plered & 25,740 & 24,407 & 50,147 \\
\hline 27 & Tengahtani & 19,472 & 18,521 & 37,993 \\
\hline 28 & Kedawung & 27,786 & 27,183 & 54,969 \\
\hline & & & & \\
\hline
\end{tabular}




\begin{tabular}{|l|l|c|c|c|}
29 & Gunungjati & 37,189 & 36,858 & 74,047 \\
\hline 30 & Kapetakan & 28,629 & 27,724 & 56,353 \\
\hline 31 & Suranenggala & 21,789 & 21,311 & 43,100 \\
\hline 32 & Klangenan & 24,589 & 22,095 & 46,684 \\
\hline 33 & Jamblang & 19,149 & 18,864 & 38,013 \\
\hline 34 & Arjawinangun & 30,814 & 26,387 & 57,201 \\
\hline 35 & Panguragan & 23,636 & 22,161 & 45,797 \\
\hline 36 & Ciwaringin & 17,000 & 16,647 & 33,647 \\
\hline 37 & Gempol & 23,253 & 22,308 & 45,561 \\
\hline 38 & Susukan & 33,819 & 33,502 & 67,321 \\
\hline 39 & Gegesik & 37,198 & 35,117 & 72,315 \\
\hline 40 & Kaliwedi & 20,681 & 20,590 & 41,271 \\
\hline & Jumlah & 1089692 & 1036486 & $2,126,178$ \\
\hline
\end{tabular}

Sumber: cirebonkab.bps.go.id

Tabel 3.4 Jumlah Penduduk Kabupaten Indramayu pada Tahun 2015

\begin{tabular}{|l|l|r|r|r|}
\hline \multirow{2}{*}{ No } & \multirow{3}{*}{ Kecamatan } & \multicolumn{3}{|c|}{$\mathbf{2 0 1 5}$} \\
\cline { 3 - 5 } & & \multicolumn{3}{|c|}{ Penduduk Menurut Jenis Kelamin (Jiwa) } \\
\cline { 3 - 5 } & & $\begin{array}{c}\text { Laki- } \\
\text { laki }\end{array}$ & Perempuan & $\begin{array}{l}\text { Laki-laki dan } \\
\text { Perempuan }\end{array}$ \\
\hline 1 & Haurgeulis & 46521 & 44451 & 90972 \\
\hline 2 & Gantar & 31349 & 30557 & 61906 \\
\hline 3 & Kroya & 32407 & 30959 & 63366 \\
\hline 4 & Gabuswetan & 28009 & 27176 & 55185 \\
\hline 5 & Cikedung & 19814 & 19502 & 39316 \\
\hline 6 & Terisi & 27958 & 26191 & 54149 \\
\hline 7 & Lelea & 24411 & 23806 & 48217 \\
\hline 8 & Bangodua & 14107 & 13523 & 27630 \\
\hline 9 & Tukdana & 26335 & 24816 & 51151 \\
\hline 10 & Widasari & 17812 & 16373 & 34185 \\
\hline 11 & Kertasemaya & 31222 & 29912 & 61134 \\
\hline 12 & Sukagumiwang & 18833 & 18776 & 37609 \\
\hline 13 & Krangkeng & 33028 & 30916 & 63944 \\
\hline 14 & Karangampel & 32913 & 30221 & 63134 \\
\hline 15 & Kedokanbunder & 23184 & 21604 & 44788 \\
\hline 16 & Juntinyuat & 41597 & 37047 & 59196 \\
\hline 17 & Sliyeg & 30837 & 28359 & \\
\hline & & & & \\
\hline
\end{tabular}




\begin{tabular}{|l|l|r|r|r|}
\hline 18 & Jatibarang & 36454 & 34097 & 70551 \\
\hline 19 & Balongan & 20044 & 18631 & 38675 \\
\hline 20 & Indramayu & 57442 & 53567 & 111009 \\
\hline 21 & Sindang & 25927 & 24636 & 50563 \\
\hline 22 & Cantigi & 16691 & 15188 & 31879 \\
\hline 23 & Pasekan & 12604 & 11531 & 24135 \\
\hline 24 & Lohbener & 28149 & 26562 & 54711 \\
\hline 25 & Arahan & 16723 & 15796 & 32519 \\
\hline 26 & Losarang & 27891 & 26142 & 54033 \\
\hline 27 & Kandanghaur & 44553 & 42050 & 86603 \\
\hline 28 & Bongas & 23878 & 22993 & 46871 \\
\hline 29 & Anjatan & 42601 & 40191 & 82792 \\
\hline 30 & Sukra & 23096 & 20788 & 43884 \\
\hline 31 & Patrol & 28824 & 26920 & 55744 \\
\hline Total & & $\mathbf{8 8 5 2 1 4}$ & $\mathbf{8 3 3 2 8 1}$ & $\mathbf{1 7 1 8 4 9 5}$ \\
\hline
\end{tabular}

Sumber: indramayukab.bps.go.id

Tabel 3.6 Jumlah Penduduk Kabupaten Majalengka Tahun 2014

\begin{tabular}{|l|r|r|r|}
\hline \multicolumn{3}{|c|}{ Jumlah Penduduk Menurut Jenis Kelamin \& Rasio Jenis Kelamin } \\
\hline \multicolumn{3}{|c|}{ Di Kabuten Majalengka Tahun 2014} \\
\hline Population and Sex Ratio by Sub-District in Majalengka Regency, 2014 \\
\hline \multirow{2}{*}{ Kecamatan } & \multicolumn{3}{c|}{ Jenis Kelamin } \\
\cline { 2 - 4 } & \multicolumn{3}{|c|}{ Sex } \\
\hline \multicolumn{1}{|c|}{ Sub-District } & Male & Female & \multicolumn{1}{c|}{ Total } \\
\hline \multirow{2}{*}{ (1) } & $(2)$ & $(3)$ & $(4)$ \\
\hline 010 Lemahsugih & 28749 & 28742 & 57491 \\
\hline 020 Bantarujeg & 21486 & 21620 & 43106 \\
\hline 021 Malausma & 20622 & 21366 & 41988 \\
\hline 030 Cikijing & 30047 & 28386 & 58433 \\
\hline 031 Cingambul & 18005 & 17805 & 35810 \\
\hline 040 Talaga & 21704 & 21112 & 42816 \\
\hline 041 Banjaran & 12046 & 12107 & 24153 \\
\hline 050 Argapura & 16859 & 17195 & 34054 \\
\hline 060 Maja & 24394 & 24266 & 48660 \\
\hline 070 Majalengka & 34704 & 35662 & 70366 \\
\hline 080 Cigasong & 17114 & 16584 & 33698 \\
\hline 090 Sukahaji & 19948 & 19891 & 39839 \\
\hline 091 Sindang & 7260 & 7275 & 14535 \\
\hline
\end{tabular}




\begin{tabular}{|l|l|l|l|}
\hline 100 Rajagaluh & 20851 & 20908 & 41759 \\
\hline 110 Sindangwangi & 15264 & 15363 & 30627 \\
\hline 120 Leuwimunding & 28068 & 29760 & 57828 \\
\hline 130 Palasah & 23000 & 24011 & 47011 \\
\hline 140 Jatiwangi & 41591 & 41460 & 83051 \\
\hline 150 Dawuan & 22421 & 22994 & 45415 \\
\hline 151 Kasokandel & 23113 & 23401 & 46514 \\
\hline 160 Panyingkiran & 14903 & 15109 & 30012 \\
\hline 170 Kadipaten & 21849 & 21570 & 43419 \\
\hline 180 Kertajati & 21303 & 20654 & 41957 \\
\hline 190 Jatitujuh & 25634 & 25283 & 50917 \\
\hline 200 Ligung & 28386 & 28132 & 56518 \\
\hline 210 Sumberjaya & 28560 & 27776 & 56336 \\
\hline & & & \\
\hline Kab. Majalengka & $\mathbf{5 8 7 ~ 8 8 1}$ & $\mathbf{5 8 8 ~ 4 3 2}$ & $\mathbf{1 1 7 6 ~ 3 1 3}$ \\
\hline
\end{tabular}

Sumber: majalengkakab.bps.go.id

Tabel 3.8 Jumlah Penduduk Kabupaten Kuningan Tahun 2014

\begin{tabular}{|c|c|c|c|c|c|c|c|}
\hline \multicolumn{8}{|c|}{ Jumlah Penduduk Menurut Kecamatan dan Agama yang Dianut } \\
\hline \multicolumn{8}{|c|}{ di Kabupaten Kuningan, 2014} \\
\hline & Kecamatan & Islam & Katholik & Protestan & Hindu & Budha & Lainnya \\
\hline 1 & Darma & 55262 & 75 & - & - & - & - \\
\hline 2 & Kadugede & 26322 & 4 & 11 & - & - & 1 \\
\hline 3 & Nusaherang & 23043 & - & 15 & - & - & - \\
\hline 4 & Ciniru & 19126 & 210 & - & - & - & - \\
\hline 5 & Hantara & 14683 & 5 & - & - & - & - \\
\hline 6 & Selajambe & 15229 & 18 & - & - & - & - \\
\hline 7 & Subang & 16820 & 59 & 36 & - & - & - \\
\hline 8 & Cilebak & 12545 & - & - & - & - & - \\
\hline 9 & Ciwaru & 30820 & 5 & - & - & - & - \\
\hline 10 & Karangkancana & 20546 & - & - & - & - & - \\
\hline 11 & Cibingbin & 41353 & - & - & - & - & - \\
\hline 12 & Cibeureum & 20262 & - & - & - & - & - \\
\hline 13 & Luragung & 46547 & 6 & 60 & - & - & - \\
\hline 14 & Cimahi & 31797 & - & - & - & - & - \\
\hline 15 & Cidahu & 44221 & - & 5 & - & - & - \\
\hline 16 & Kalimanggis & 25922 & - & - & - & - & - \\
\hline 17 & Ciawigebang & 92082 & 7 & - & - & - & - \\
\hline 18 & Cipicung & 28773 & 11 & - & - & - & - \\
\hline 19 & Lebakwangi & 43505 & 50 & 8 & - & - & - \\
\hline 20 & Maleber & 45712 & - & 4 & - & 6 & - \\
\hline
\end{tabular}




\begin{tabular}{|r|l|r|r|r|r|r|r|}
\hline 21 & Garawangi & 42136 & 406 & 300 & - & - & - \\
\hline 22 & Sindangagung & 35559 & 14 & - & - & - & - \\
\hline 23 & Kuningan & 90845 & 1081 & 1446 & 30 & 148 & 65 \\
\hline 24 & Cigugur & 38659 & 4904 & 255 & 3 & 8 & - \\
\hline 25 & Kramatmulya & 43116 & 5 & 11 & - & - & - \\
\hline 26 & Jalaksana & 42123 & - & - & - & - & - \\
\hline 27 & Japara & 21695 & - & - & - & - & - \\
\hline 28 & Cilimus & 49741 & 15 & 10 & - & - & - \\
\hline 29 & Cigandamekar & 30693 & 1 & - & - & - & - \\
\hline 30 & Mandirancan & 25114 & - & 5 & - & 5 & - \\
\hline 31 & Pancalang & 24400 & - & - & - & - & - \\
\hline 32 & Pasawahan & 24524 & - & - & - & - & - \\
\hline & & & & & & \\
\hline
\end{tabular}

Jumlah Anggaran Belanja dan Penerimaan Desa Astana Kecamatan Gunungjati Kabupaten Cirebon pada tahun 2017 sebesar Rp. 282.511.000,00. Bantuan dari Pemerintah Provinsi sebesar Rp. 115.000.000,00, Pendapatan Asli Desa sebesar Rp 16.000.000,00, Alokasi Dana Desa sebesar Rp. 151.511.000,00. Sedangkan jumlah Belanja Publik/ belanja pembangunan yang dikeluarkan oleh desa sebesar Rp 22.500.000,00 dan Jumlah Belanja Aparatur/pegawai sebesar Rp. 119.100.000,00.

Jumlah Aggaran Belanja dan Penerimaan Desa Ciawigajah Kecamatan Beber Kabupaten Cirebon pada Tahun 2017 sebesar Rp. 602.805.000,00. Sumber anggaran terdiri dari APBD Kabupaten sebesar Rp. 177.255.000,00, Bantuan Pemerintah Kabupaten sebesar Rp. 162.255.000,00, Bantuan Pemerintah Provinsi sebesar Rp. 15.000.000,00, Pendapatan Asli Desa sebesar Rp. 425.550.000,00. Alokasi dana desa sebesar Rp 162.255.000,00 dan sumber pendapatan dari perusahaan yang ada di desa/kelurahan $\operatorname{Rp} 21.500 .000,00$.

Desa sebagai garda terdepan pembangunan mempunyai peran yang strategis dalam menyukseskan program nawacita. Pengelolaan anggaran desa berdasarkan asas transparan, akuntabel, partisipatif, efisien, efektif, tertib dan disiplin anggaran dengan memperhatikan asas keadilan, kepatutan dan manfaat bagi masyarakat desa. Dalam prakteknya untuk mewujudkan pemerataan pembangunan, dilaksanakan melalui tahapan sebagai berikut :

1. Perencanaan yang dituangkan dalam bentuk Rencana Kerja Pemerintah Desa (RKPDes) melalui musdes dengan melibatkan berbagai komponen masyarakat 
untuk menjaring kebutuhan masyarakat dan diharmonisasi dengan Rencana Pembangunan Jangka Menengah Desa (RPJMDes);

2. Penyusunan APBDes yang dibahas dan disepakti bersama antara Pemerintah Desa denggan Badan Permusyawaratan Desa (BPD) dengan penajaman skala prioritas dalam RKPDes;

3. Pelaksanaan kegiatan dalam APBD dilaksanakan oleh Tim Pelaksana Kegiatan yang terdiri dari unsur perangkat desa dan Lembaga kemasyarakatan dan diawasi oleh BPD

4. Dalam rangka transparansi anggaran, pemerintah desa melakukan publikasi APBDes tahun berjalan dan resume Laporan APBDes tahun sebelumnya dalam bentuk baligho maupun selebaran yang dipasang ditempat strategis dan mudah diakses oleh masyarakat;

5. Setiap akhir tahun anggaran Kepala Desa mempunyai kewajiban menyampaikan Laporan Penyelenggraaan Pemerintaha Desa (LPPD) kepada Bupati melalui camat dan menyampaikan Keterangan atas LPPD kepada BPD;

6. Dalam rangka mendukung akuntabilitas pengelolaan keuangan desa, desa menggunakan aplikasi Sistem pengelolaan Keuangan Desa (SISKEUDES)

Secara umum tata kelola anggaran yang bersumber dari APBD dalam bentuk Dana Desa adalah :

1. Pada prinsipnya pengelolaan dana Desa dalam kegiatan pembangunan dan pemberdayaan dilaksanakan secara swakelola dengan melibatkan sumberdaya manusia dan dan sumberdaya lokal sehingga terjadi perputaran Dana Desa lebih lama di desa dan dirasakan olah banyak komponen masyarakat;

2. Kebijakan pemerintah dalam rangka Padat Karya Tunai memberikan kesempatan lebih banyak kepada masyarakat untuk turut serta dalam kegiatan pembangunan dan di sisi lain memberikan penghasilan kepada masyarakat penganggur atau setengah penganguran;

3. Kegiatan pembangunan sampai dengan saat ini lebih diditikberatkan kepada upaya pemenuhan prasarana sosial dasar berupa infrastrukur perdesaan meliputi jalan desa, jalan usaha tani, irigasi pedesaan, embung, sarpras pertanian, air bersih, sarpras dan operasional bidang kesehatan di luar urusan kabupaten, sarpras dan operasional bidang pendidikan di luar urusan kabupaten. 


\section{PENUTUP}

Desa sebagai garda terdepan pembangunan mempunyai peran yang strategis dalam menyukseskan program nawacita. Pengelolaan anggaran desa berdasarkan asas transparan, akuntabel, partisipatif, efisien, efektif, tertib dan disiplin anggaran dengan memperhatikan asas keadilan, kepatutan dan manfaat bagi masyarakat desa. Pelaksanaan kegiatan dalam APBD dilaksanakan oleh Tim Pelaksana Kegiatan yang terdiri dari unsur perangkat desa dan Lembaga kemasyarakatan dan diawasi oleh BPD. Setiap akhir tahun anggaran Kepala Desa mempunyai kewajiban menyampaikan Laporan Penyelenggraaan Pemerintaha Desa (LPPD) kepada Bupati melalui camat dan menyampaikan Keterangan atas LPPD kepada BPD.

Pada prinsipnya pengelolaan dana Desa dalam kegiatan pembangunan dan pemberdayaan dilaksanakan secara swakelola dengan melibatkan sumberdaya manusia dan dan sumberdaya lokal sehingga terjadi perputaran Dana Desa lebih lama di desa dan dirasakan olah banyak komponen masyarakat.

Kegiatan pembangunan sampai dengan saat ini lebih ditiikberatkan kepada upaya pemenuhan prasarana sosial dasar berupa infrastrukur perdesaan meliputi jalan desa, jalan usaha tani, irigasi perdesaa, lumbung, sarpras pertanian, air bersih, sarpras dan operasional bidang kesehatan di luar urusan kabupaten, sarpras dan operasional bidang pendidikan di luar urusan kabupaten.

\section{DAFTAR PUSTAKA}

\section{Buku, Artikel}

Aprillia et.all. 2014.Pembangunan Berbasis Masyarakat, Alfabet, Bandung.

Badan Pengawas Keuangan dan Pembangunan. 2015 Petunjuk Pelaksanaan Bimbingan dan Konsultasi Pengelolaan Keuangan Desa. Deputi Bidang Pengawasan Penyelenggaraan Keuangan Daerah.

Bungin Burhan. 2007. Penelitian Kualitatif: Komunikasi, Ekonomi, Kebijakan Publik, dan Ilmu Sosial Lainnya. Kencana Prenada Media Group. Jakarta.

Dewanti, Elsa Dwi Wahyu, Sudarno dkk. 2016. Analisis Perencanaan Pengelolaan Keuangan Desa di Desa Boreng (Studi Kasus pada Desa Boreng Kecamatan Lumajang Kabupaten Lumajang. FE Universitas Jember.

Hasan, Djuhaendah. 2006.Makalah Aspek Hukum Ekonomi dalam Pengadaan Tanah untuk Kepentingan Pembanguanan, Jakarta. 
Peter, Hagul. 1985. Pembangunan Desa dan Lembaga Swadaya Masyarakat, CV Rajawali, Jakarta.

Rinusu dan Sri Mastuti. 2003. Panduan Praktis Mengontrol APBD. Jakarta: Civic Education dan Budget Transperency Advocation (CiBa) \& Friedrich Ebert Stiftung (FES)

Mardikanto, Totok et.all. 2013. Pemberdayaan Masyarakat, Alfabeta, Bandung.

Nasution, S. dan Thomas, M. 1994. Buku Penuntun Membuat Thesis, Skripsi, Disertasi, Makalah, Bumi Aksara, Jakarta.

Sastramiharja Zaenal Arifin. 1995. Pendekatan Pembangunan Pedesaan, Kantor Pembangunan Masyarakat Desa Pemerintah Provinsi Jawa Barat.

Sujarwo Marsoem at all, 2015. Ganti Untung pengadaan Tanah Memetakan Solusi Strategis Pembanguan Infrastruktur Di Indonesia, Renebook, Jakarta.

Sumardjono, Maria., S. W. 1989. Pedoman Pembuatan Usulan Penelitian, Yogyakarta.

Sunaryati Hartono. 1988. Hukum Pembangunan Ekonomi Pembangunan Indonesia, Binacipta, Bandung.

Waty Suwarty Hartono. 2011. Hukum Lingkungan, UIJ.

\section{Peraturan Perundang-undangan}

Permendagri No. 56 Tahun 2015 tentang Kode dan Data Wilayah Administrasi Pemerintahan.

Peraturan Menteri Dalam Negeri No. 113 Tahun 2014 tentang Pedoman Pengelolaan Keuangan Desa.

Peraturan Menteri Dalam Negeri No.114 Tahun 2014 tentang Pedoman Pembangunan Desa

\section{Internet}

www.indonesiacayo.com. Diunduh pada tanggal 5 Oktober 2017 Pukul 19.30

www.kompasiana.com. Diunduh pada tanggal 5 Oktober 2017 Pukul 19.35

Repository.upi.edu diunduh pada tanggal 5 Oktober 2017 Pukul 19.43

http://kedesa.id diunduh pada tanggal 5 Oktober 21.30

http://www.presidenri.go.id diunduh pada tanggal 5 Oktober 06.30 